\title{
Role of land set-up systems on soil (physicochemical) conditions
}

\author{
Stefania Cocco, ${ }^{1}$ Valeria Cardelli, ${ }^{1}$ Giuseppe Corti, ${ }^{1}$ Dominique Serrani, ${ }^{1}$ \\ Rogério Borguete Alves Rafael, ${ }^{2}$ Carmelo Dazzi, ${ }^{3}$ Giuseppe Lo Papa ${ }^{3}$ \\ ${ }^{1}$ Department of Agricultural, Food and Environmental Sciences, Università Politecnica delle Marche, \\ Ancona, Italy; ${ }^{2}$ Department of Rural Engineering, Faculty of Agronomy and Forestry Engineering, \\ Universidade Eduardo Mondlane, Maputo, Mozambique; ${ }^{3}$ Department of Agricultural, Food and Forest \\ Sciences, Università di Palermo, Italy
}

\begin{abstract}
Land reclamation and drainage networks represent one of the most ancient human modifications of the Italian soilscape, where tailored land set-up systems were developed in agro- and forestecosystems in three millennia of man's activity. Most of once manually maintained land settings are currently scarcely working or even disappeared because of the cost needed for their maintenance and the advent of mechanization that have simplified the field organization. The scarce attention to the soil experienced in the last decades, has accelerated soil erosion and flooding events, which entailed high costs in terms of money and human lives, but also caused reduction of soil thickness, water holding capacity, and fertility. In view of a sustainable agriculture, it is mandatory to assess the role of land set-up systems, which for centuries have been key in protecting soil from erosion, but also in increasing soil fertility. Such an effort cannot be made without considering the different pedo-climatic conditions and land uses of the Italian territory, which is different with respect to the past because of the multiple transformations made to favour the mechanization of agriculture. In this review we discuss the main effect of Italian land settings on the soilscape and on soil physicochemical conditions. Since land settings were developed centuries ago, detailed information about their effect on specific soil parameters is scarce in the scientific literature; thus, in some case, we provide information gathered in places where land set-up systems are still present.
\end{abstract}

Correspondence: Valeria Cardelli, Department of Agricultural, Food and Environmental Sciences, Università Politecnica delle Marche, Via Brecce Bianche 10, 60131 Ancona (AN), Italy.

E-mail: v.cardelli@staff.univpm.it

Key words: Land reclamation; time of concentration; soil fertility; soilscape; soil erosion.

Received for publication: 29 October 2020.

Accepted for publication: 8 November 2020.

(C) Copyright: the Author(s), 2020

Licensee PAGEPress, Italy

Italian Journal of Agronomy 2020; 15:1766

doi:10.4081/ija.2020.1766

This article is distributed under the terms of the Creative Commons Attribution Noncommercial License (by-nc 4.0) which permits any noncommercial use, distribution, and reproduction in any medium, provided the original author(s) and source are credited.

\section{Introduction}

Land reclamation and drainage networks represent one of the most ancient human modifications of the landscape made with the aim to increase crop yield or to preserve forest functionality through the improvement of soil physical, chemical, and biological conditions and the reduction of the water erosion (Landi, 1999; Corti et al., 2013; Sofia et al., 2014). In the Italian soilscape, pedoclimatic regions and land set-up systems result from interactions among factors like geology, morphology, climate, vegetation, soil management, and land use (Corti et al., 2013; Costantini et al., 2013). Therefore, the various agro- and forest-ecosystems generated by the combination of natural and human factors in three millennia of man's activity in the Italian territory, different land setup systems were developed. Roughly, four main plans of interventions have been designed on the base of the principal necessities: i) in mountain and hilly environments with moderate to steep slopes, soils are affected by water runoff and accelerated erosion and, in time, land settings able to favour both water infiltration and soil protection were designed; ii) in plain territories with lithology dominated by fine sediments, soils are generally affected by excess of water and people have developed drainage and hydraulic land settings to ensure rapid water discharge and soil aeration; iii) in areas affected by aridity, which are particularly diffused in southern Italy, land settings and dry-farming systems able to preserve water in the sub-soil are required; iv) in the whole country, even though at a lower level of engineering development, also forest environments were provided of land settings able to reduce soil erosion, mainly on steep slopes.

Unfortunately, especially in the agro-ecosystems, most of once manually maintained land settings are nowadays scarcely working or even disappeared because of the cost needed for their maintenance and the advent of mechanization. Yet, in the last decades, flooding events have represented an increasing threat for both farmers and downstream communities of the country, with high costs in terms of money and human lives. Among the reasons considered responsible for these even more frequent events, the reduction of the time of concentration due to the increase of runoff certainly plays an important role. This phenomenon is then associated with accelerated soil erosion, which is responsible to reduce soil thickness and, consequently, water holding capacity and soil fertility, so triggering a negative feedback that hold the soils in an early stage of evolution (Entisols, according to the SSS, 2014). In effect, the so called 'Entisolization' has been considered one of the most modern soil threats, also able to decrease both pedodiversity and biodiversity (Lo Papa et al., 2011; Dazzi and Lo Papa, 2013). However, we have no experimental data concerning soil loss before 1950s, when land settings and soil preservation techniques were implemented, and soil conservation received more attention 
than nowadays. Consequently, it is mandatory to assess the role of land set-up systems, which for centuries have been key in protecting soil from erosion (and lowlands from flooding events), but also in increasing soil water availability and soil fertility. However, such an effort cannot be made without taking into consideration the different pedo-climatic conditions and land uses of the Italian territory, which nowadays is however different with respect to that before $1950 \mathrm{~s}$ because of the multiple transformations made to favour agriculture mechanization. Unfortunately, while we adopted mechanization, we neglected the reason why land set-up systems were developed.

In this review we discuss the main effect of Italian land settings on the soilscape and on the soil physicochemical conditions. Since land settings were developed centuries ago (mainly starting from the $18^{\text {th }}$ century), detailed information about their effect on specific soil parameters are scarce in the scientific literature; because of this, in some case, we provide information obtained from soil profiles opened in places where land set-up fields were nearby to not land set-up fields.

\section{General features about the Italian landscapes and agri- cultural and forest land set-up systems}

According to Istat (2013), Italian territory is made of $\approx 35 \%$ mountain, $\approx 42 \%$ hill, and $\approx 23 \%$ plain. Mountain area is mainly represented by two main mountain ranges: the Alps, which represent about $1 / 4$ of the total Italian land surface $\left(\approx 75,000 \mathrm{~km}^{2}\right)$, and the Apennines, which account for $\approx 40 \%\left(\approx 120,000 \mathrm{~km}^{2}\right)$. The Italian territory offers a remarkable landscape diversity because of the frequent spatial change of environmental factors (Corti et al., 2013). Due to such diversity and considering that agriculture is the main soil use all over the country, the Italian soilscape requires attention since it is frequently prone to erosion risks.

In Italy, a country-wide mechanization occurred after the end of World War II and, in particular, after the end of the sharecropping farming (due to the law \#756 of the year 1964). Since then, the diffusion of agrochemicals and the increasing costs of agricultural labour have led to a progressive simplification of Italian agroecosystems (Corti et al., 2013), and the landscape has been subjected to many changes. Here below, we offer a short list of the major general changings occurred in the landscape in the last 5070 years, with no judge about the reasons of their changing:

i) Vineyards with grapevines raised on live supports like maples (Acer spp.), elms (Ulmus sp..), and limes (Tilea spp.), which represented occasional sources of fodder, firewood, and silkworm feed, have been totally removed; the same happened to thousands of isolated grapevines raised on living supports once spread in fields devoted to cereals and hay production. Nowadays, only specialized vineyards are present in Italian territory.

ii) The 'Mediterranean openfield' known as alberata padana (meaning tree lines of the Po valley), once diffused in the river Po Valley, consisted of fields delimited by hedges, scarps, and drainage ditches that formed a deep and well outlined hydrographic network able to discharge the excess of water (Calzecchi Onesti, 1957; Desplanques, 1975; Sereni, 1961). This set-up system has been transformed into plain openfield by eliminating any obstacle to agricultural machinery.

iii) Because of the downfall of silk production, during the second half of the $20^{\text {th }}$ century, hundreds of kilometres of mulberry rows that supported the Italian silk industry have been reduced to few individual trees at the margin of the fields. At the beginning of $21^{\text {st }}$ century, mulberry tree rows separating fields used for cereal and hay production survived only in the EmiliaRomagna region, in a few sites from Piacenza to Bologna (Zimmermann, 2006). Nowadays, this field arrangement is almost disappeared with the only exception of very small patches in marginal areas of central and south Italy.

iv) In central Italy, classical arboreal-herbaceous intercropping aiming at protecting hilly soils from erosion has disappeared since the 1960s, and only relicts of this field arrangement actually persist in Tuscany, Umbria, and Marche, usually in form of very old olive trees and grapevine rows. This intercropping has been erased to be replaced by large vineyards or olive groves, separated by fields devoted to cereal crops.

As observed by Costantini and Barbetti (2008) in their study on viticulture and olive tree cultivation impact in Siena province, a new landscape made of permanent/specialized monocultures with Mediterranean industrial scale has been created since the end of the sharecropping farming, often neglecting soil managing practices and increasing soil erosion risks. These authors underlined how soil erosion risk and soil management difficulty almost doubled in the transition from traditional intercropping to the specialized tree cultivation and how the generalised adoption of along the maximum slope gradient mechanical works (in Italian called rittochino) in vineyards and olive groves caused the impairment of soil hydrological systems. The, also Vineyard Landscape of Piedmont: Langhe, Roero and Monferrato, which has been recognized as UNESCO World Heritage Site, is threatened by soil erosion since the ancient land setting was cancelled. In this contest, Bagagiolo et al. (2018) remarked the fundamental role of contour-slope row orientation in reducing runoff and soil losses, disregarding the adopted inter-rows soil management. Because of these changes, especially in central Italy, in most of the soils originated from silty Pliocene and Plio-pleistocene sedimentary rocks (mostly Inceptisols), both soil erosion and mass movement are widespread forms of land degradation. It is important to remark that, even if the origin of badlands is attributed to numerous variables interacting together (e.g., Vergari et al., 2013; Carballo-Arias and Ferro, 2016), forest clear cutting and intensive exploitation of fine textured soils submitted to climate regimes concentrating rainfalls in two main periods (Autumn and early Spring) are considered the main causes for historical development of Italian badlands known as calanchi (Corti et al., 2013; Cocco et al., 2015). Since the formation of land degradation features like rills, gullies, and piping due to human activity is considered among the first steps in the soil denudation processes that lead to the calanchi formation (e.g., Torri et al., 1994; Torri and Bryan, 1997), in the soils more prone to this type of degradation it is mandatory to adopt all attentions to prevent the development of these features. Actually, in changed rural landscape, much attention is paid on the effects of different soil managements such as grass cover and no tillage on soil erodibility (Corti et al., 2011), often neglecting other important aspects like soil thickness reduction, erasing of B horizons (Costantini and Barbetti, 2008), Entisolization (Lo Papa, 2013), and the deterioration of hydrological equilibrium of the slopes (Agnoletti et al., 2019). While agricultural soils in the last 50-60 years have experienced a profound crisis of fertility and reduction of the water holding capacity because of their thickness reduction, forest soils have suffered for abandonment and maintenance of artefacts like ditches (Figure 1), terraces, charcoal kilns (Carrari et al., 2017), gulches, and forest roadsides, which ensured man's presidium of the forests and rapid possibility of intervention in case of fire or forest cut. All these artefacts and land works have ensured a certain erosion control for centuries, and the abandonment has favour activation of erosion phenomena in the abandoned forests. 


\section{Agro-ecosystems}

\section{Mountain land}

Apennines have been triggered by depopulation in the last 5060 years. At a large scale, in rural Italian mountain areas as well as in other southern European countries, the abandonment of traditional human presidium of the territory has brought to the decline of crops and grasslands as woodlands expanded at the expense of the fields (Bracchetti et al., 2012). In sectors of Apennines like Apuane and others belonging to the Modena province and Marche region (in central Italy), the decline of the mountain population has caused a mosaic of transformation besides the alteration of structure, density, and the specific composition of tree vegetation (Agnoletti, 2007). The elements that are most likely to disappear from these areas are chestnut groves, meadows, pastures, pastures with trees, and cultivated lands. Further, it has been found a relationship between landslides and changes in land use linked to abandonment of chestnut groves due to the lack of maintenance of the main mountain land set-up system and terracing (Agnoletti, 2007).

Terracing represents one of the most ancient and conspicuous agricultural landscapes in mountain and hilly regions of the Mediterranean basin and the most significant and characteristic anthropogenic process of land modelling (Sandor, 2006; Dazzi and Costantini, 2015). This land setting is diffused in most of the steep slopes and typically consists of a flat platform (or terrace bed) devoted to cultivation, and an almost vertical riser protected by a dry-stone wall. The height of the riser generally varies between 1 and $2 \mathrm{~m}$, but occasionally may reach 4-6 m, depending on general hillslope gradient and the size of the cultivation platforms (Table 1). The soil filling the gap between the wall and the natural surface is generally allochthonous, namely made of terrigenous materials moved from other sources. Terracing is a common land management in Alpine and Apennine areas, where soil needs to be stabilized and soil erosion halted (Stanchi et al., 2012, 2013). Terraces have important effects on the landscape hydrology and morphology as they alter the slope gradient and length, and frequently include artificial drainage channels and irrigation ditches. Terraced slopes represent the optimum to exploit mountain territories and regulate water discharge. Impressive terracing is diffused across the Alps (Val d'Aosta, Lombardia, Trentino Alto Adige, Veneto, Friuli Venezia Giulia), and Apennines (Tuscany, Umbria, Campania, Sicily), where they have an undeniable identity, heritage, and historic value, and represent the ancient sustainable soil management to protect mountain areas from erosion and valley floors from floods (e.g., Scaramellini and Varotto, 2008). Terraces are even actually occupied by cultivations like vineyards (even at
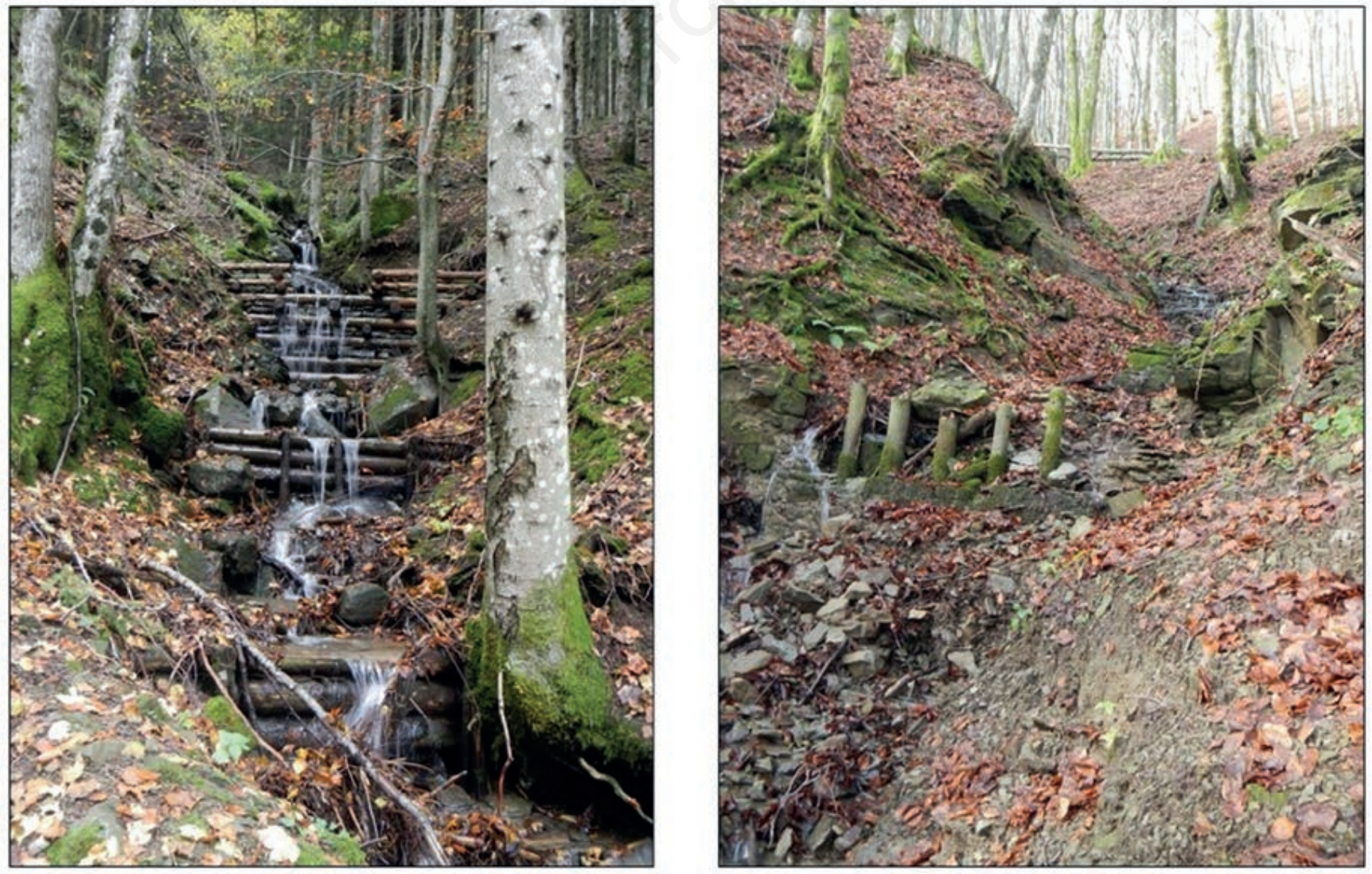

Figure 1. Example of forest land set-up setting: stabilized natural ditches to slow down the deepening of the gulch. Casentino Forests, Arezzo, Italy. 


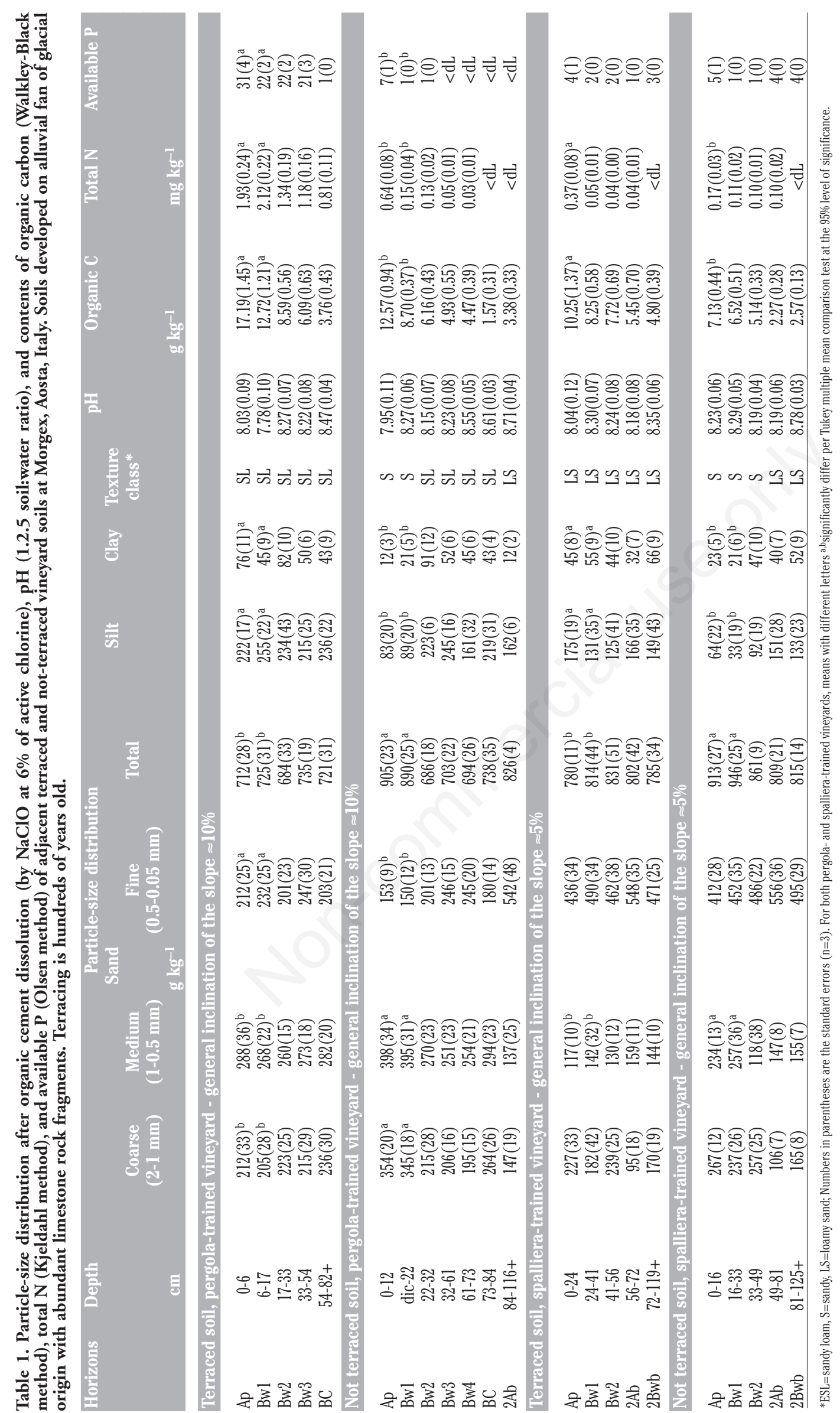


altitudes close to $1000 \mathrm{~m}$; Figure 2), fruit tree groves and sometimes cereals (Freppaz et al., 2008; Di Peco et al., 2009; Stanchi et al., 2012). Pedogenesis on terraces occurs under a strong human influence and soils are made of a human-reworked substrate frequently with a coarse texture and a shallow lithic contact (Phillips and Marion, 2004) (Figure 3). However, in general, soil on terraces show moderate to low fertility, which may decrease in case terrace management is not efficient. In some places like in mountain territories of Val d'Aosta, to improve accessibility, mechanization, and irrigation, terraces have been completely remodelled and rebuilt. As reported by Curtaz et al. (2015), soils modified by land-reshaping operations showed a simpler morphology and different physicochemical properties. According to these authors, soil structure and consistency, that are recognized as soil physical quality indicators, after a sharp negative effect ascribed to the disturbance (i.e., decrease in liquid limit, increased soil aggregates loss) showed a trend towards the restoration of the characteristics of the original soils in the medium or long-term time span. Because of the strongly reduced erosion, terraced soils are usually more fertile than not-

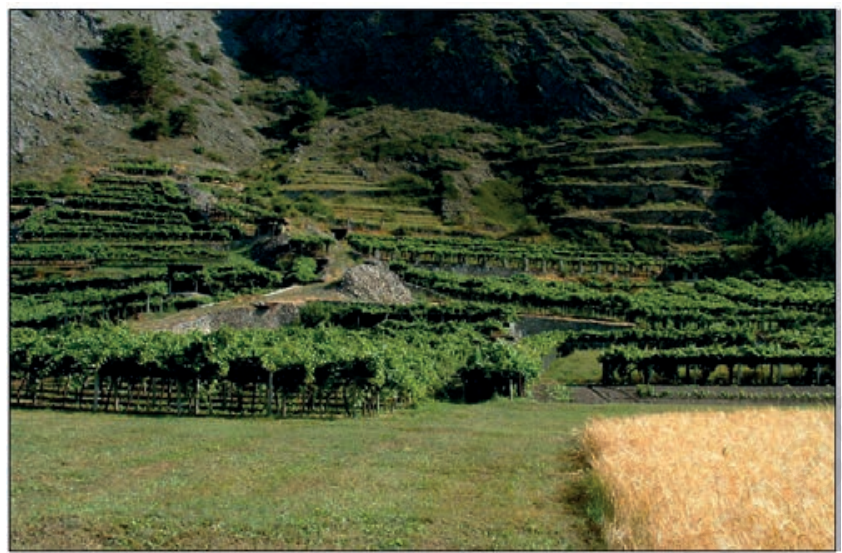

Figure 2. Example of terracing on alluvial fan of glacial origin made with the double aim to stabilize the slope and form surfaces where to cultivate grapes. Terracing faces southern exposure and spans from about 950 to about $1000 \mathrm{~m}$ above sea level. Morgex, Aosta, Italy. terraced soils and can sustain long-term stable productions. For instance, in Val d'Aosta (northern Italy), the terraced soils showed more fine particles (silt + clay), organic carbon, total nitrogen and available phosphorus than the adjacent not-terraced soils, which showed more sand and less nutrients contents (Table 1). These results demonstrate the role of terracing on erosion control and its benefit in decreasing nutrients leaching from the soil.

In Table 2 we report a list of land set-up systems adopted in several parts of Italy for managing mountain and hilly soils with the aim to balance both needs to preserve water and soil. The information relative to the types of soil on which the land settings were applied has been recovered by surveys on landscapes where land settings were or are still working.

\section{Hilly land}

The hydraulic land settings in the hilly land are fundamental to control soil erosion by reducing runoff and favouring water infiltration. Since the first occupation of the hilly land, farmers tried to exploit new areas for agricultural uses and, at the same time, maintain and improve soil quality together with landscape structure and heterogeneity (Corti et al., 2013). The need to discharge surface waters to preserve soil against erosion was the inspiring principle behind field formation and drainage of hilly terrains.

Terracing is diffused even in hilly lands where the abundance of stone has allowed their constructions centuries ago. Unfortunately, most of these lands nowadays represents marginal areas that in the last 50 years have been subject to abandonment, with consequent terrace failure and increment of gully erosion. Three different terraced from Cinque Terre (Liguria), Chianti classico (Tuscany), and Amalfi coast (Campania) show heavy damaged walls (Tarolli et al., 2014), and the same situation has been described by Mauro (2015) for terraced coastal area of Trieste (northeastern Italy), and by Barbera et al. (2009) for areas of Sicily, where the absence of maintenance of the terraces has reduced of several time folds the drainage capacity of the water network surface, increasing the hydrological risks.

A considerable amount of southern and central Italy hosts soils developed from pyroclastites. These soils show a good suitability for both agricultural and forest uses and, where they displayed problems of coherence, they have been frequently terraced. Most of these soils are devoted to intensive horticulture, vineyard, and
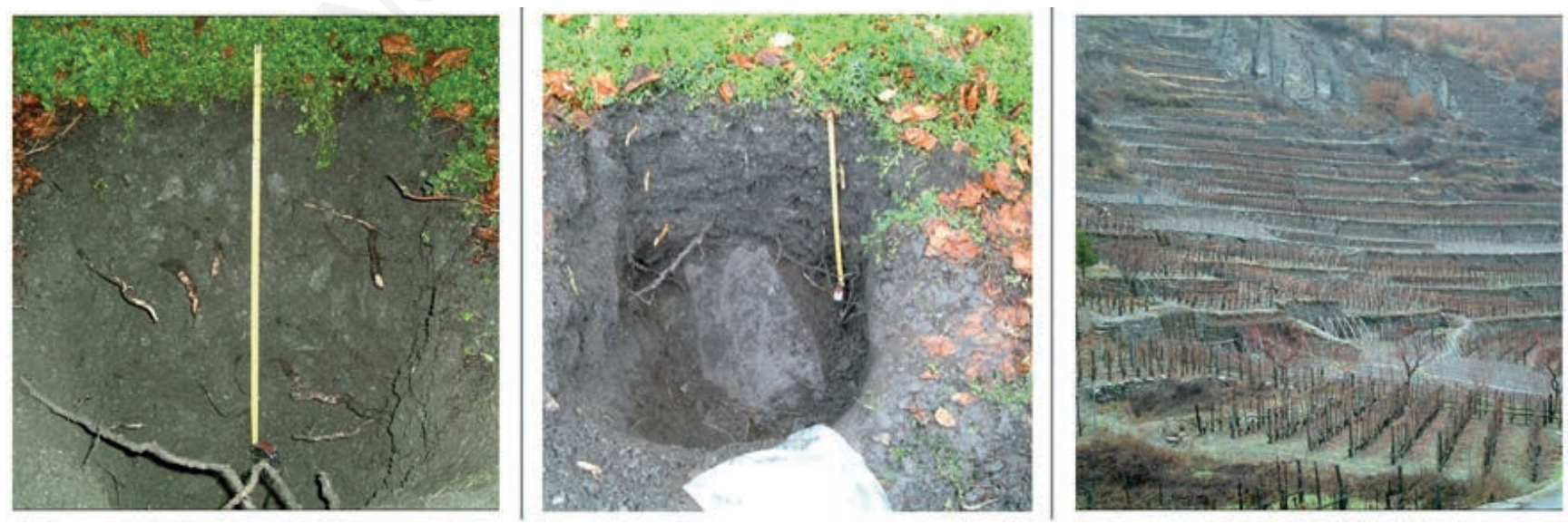

Figure 3. Examples of soil profiles on terraced slope. Soil parent material is made by in situ material and allochthonous material recovered from the surroundings. The profile on the left has a considerable depth (more than $1 \mathrm{~m}$ ) and shows small greyish coloured rock fragments of volcanic origin that are part of the autochthonous parent material; the profile on the right is shallow (about $40 \mathrm{~cm}$ deep) with the presence of shale boulders. Profiles are in a southern exposed slope at about $980 \mathrm{~m}$ above sea level. Morgex, Aosta, Italy. 


\section{प्र}
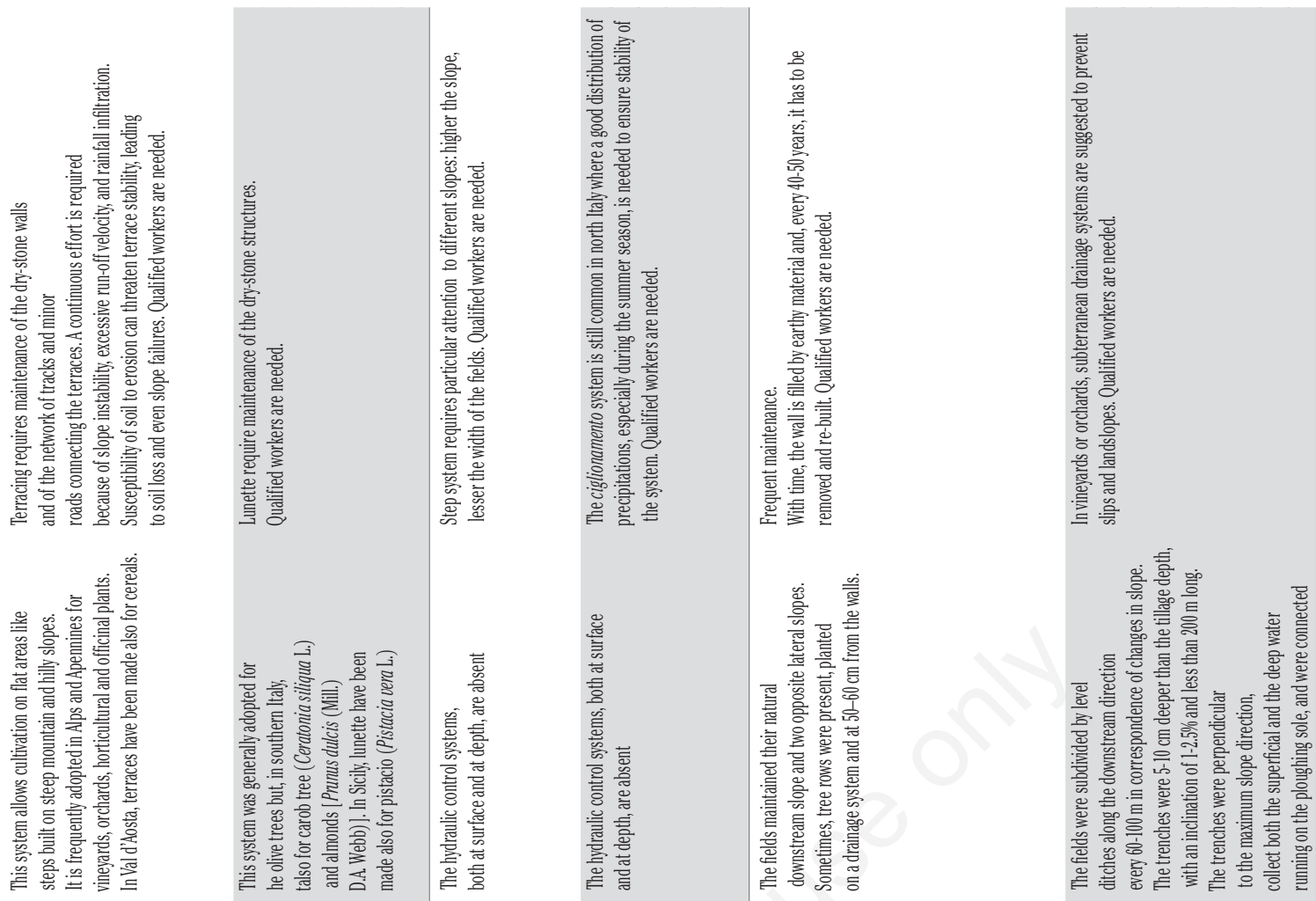

炡

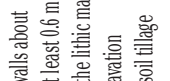

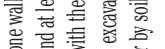

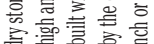

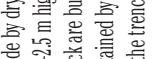

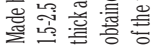

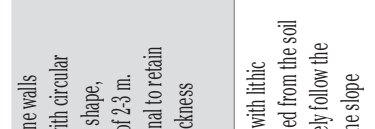

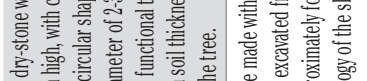

을

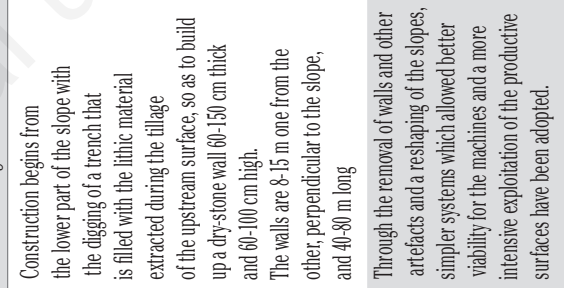

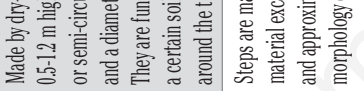

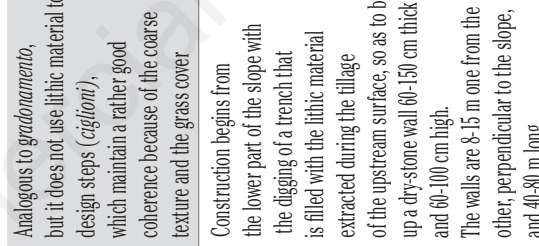

혼
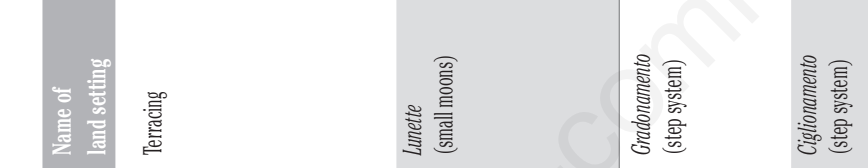

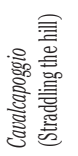

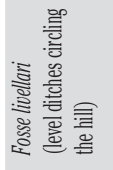

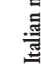

는

IIIII

\section{villin}

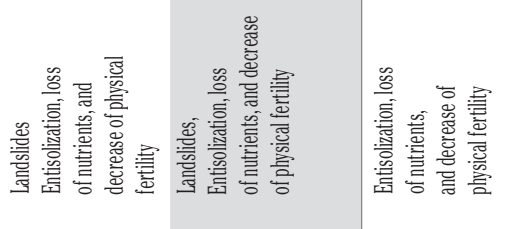

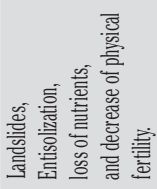

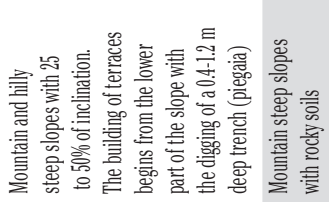
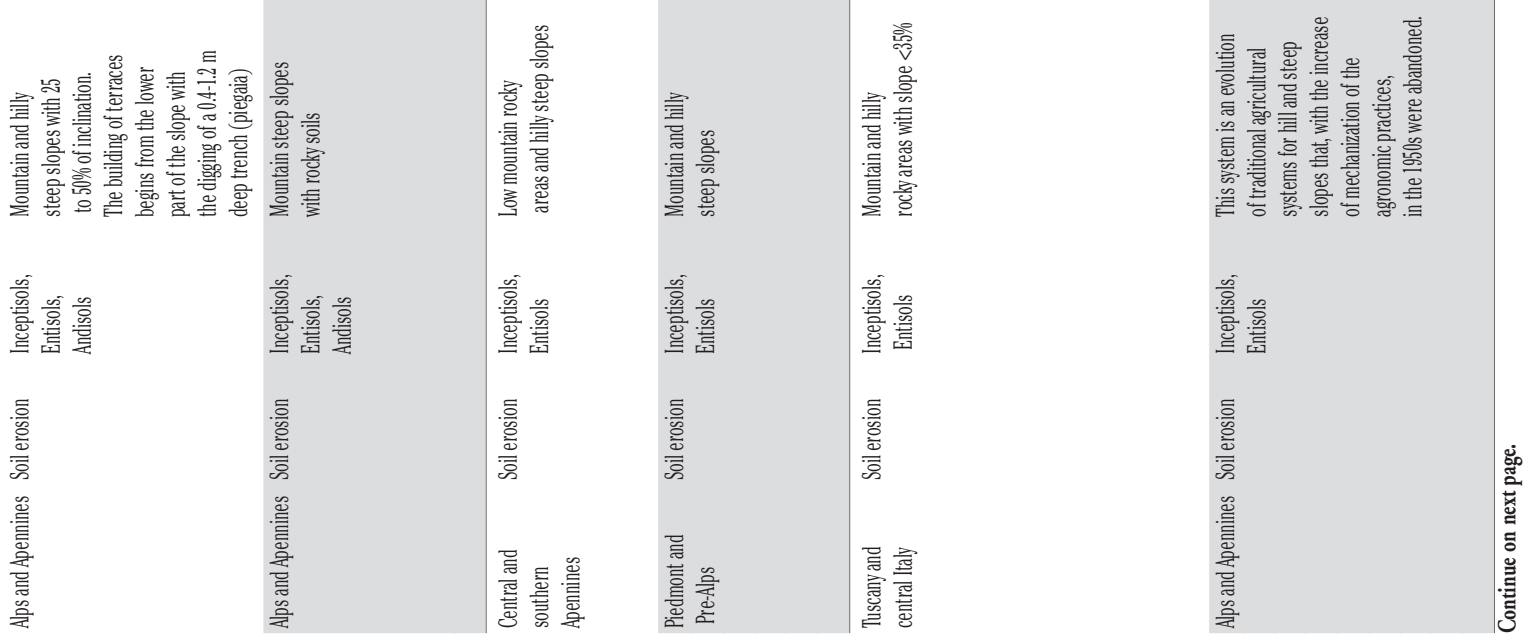


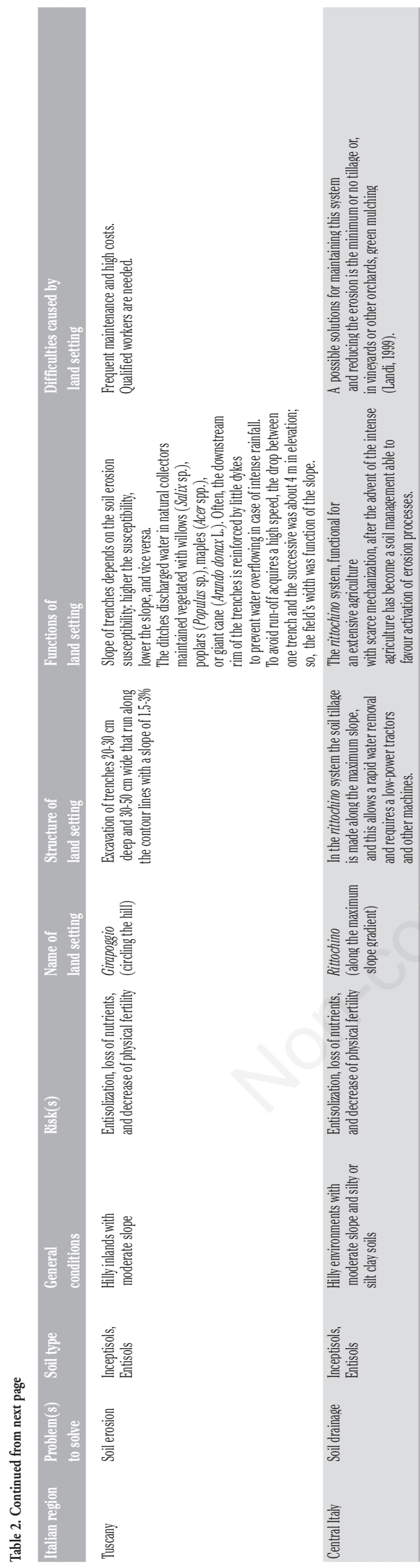

cultivation of fruits tree and flowers, while the steep slopes, sometime terraced, are occupied by woods made of Turkey oak (Quercus cerris L.), beech (Fagus sylvatica L.), and chestnut (Castanea sativa Mill.) (Agnelli et al., 2007). When these volcanic soils are well-developed (Andisols) they are susceptible to heavy machine disturbance as they have low bulk density and lack of cohesion and, especially on slope, they may reach the liquid limit and collapse because of their thixotropic properties (Dazzi, 2007). Sloping Andisols or soils with andic properties, in absence of hydraulic land settings, are therefore prone to catastrophic landslides and soliflucions as demonstrated by past disasters in the provinces of Naples, Caserta, and Salerno (Esposito et al., 2017).

Hills characterize the landscape of any Italian region. At the margin of the Alps there are the so-called Pre-Alps, which divide the high mountain from the Po plain and embrace different regions devoted to high-quality wine production like Friuli Venezia Giulia, Veneto, Trentino-Alto Adige, and Piedmont. In this latter region, vineyards are generally planted following the contour and, especially in areas with fine sedimentary lithologies, soils are protected against water erosion by grass cover (Corti et al., 2011). In the southern part of the Monferrato area, vineyards lie on Pleistocene fluvial terraces with clay to clay-loam textured soils belonging to the order of Entisols (in particular Typic Udorthents, SSS, 2014). In two vineyard plots with rows along the contour lines and in two plots with rows along the maximum slope gradient, Bagagiolo et al. (2018) compared for some years the effects of different interrow managements and rainfall characteristics on runoff and soil loss. Here, after 'intense' rainfall events, soil loss was $0.7 \mathrm{Mg} \mathrm{ha}^{-1}$ in tilled plots with rows along the contour lines and, in plots with rows along the maximum slope gradient, 21.2 and $3.4 \mathrm{Mg} \mathrm{ha}^{-1}$ in the tilled and grass cover plots, respectively. In conclusion, the grass cover was effective in decreasing runoff and soil losses during most of the events, especially during the summer storms, and results show the fundamental role of contour-slope row orientation in reducing runoff and soil losses, disregarding the adopted interrows soil management.

In central Italy, especially in Tuscany, there are many hilly hydraulic land settings as reported in Table 3. Along the Adriatic regions, soils show clay loam, silty clay loam, or silty clay textures (sensu SSS, 2014) since they evolved on plio-pleistocene pelitic marine sediments parent materials; even though the soils are particularly prone to erosion because of their fine texture, the most diffuse land setting is rittochino (along the maximum slope gradient ploughing), which in the last decades has been causing a strong reduction of soil thickness since it has favoured accelerated erosion. This process has converted many Inceptisols to Entisols (Entisolization), with a considerable decrease of fertility. Moreover, in most of the Adriatic regions, soils show middle-high plasticity and sodic properties, which make clay easily dispersible when wetted. Frequently, the nature of these soils, the soil erosion, the hill morphology, the seasonal rain distribution, and frequent unsuitable soil managements have caused rapid structure decline and changed the soil hydrologic equilibrium, with consequent formation of badlands (Cocco et al., 2015). In the soils of these areas, after rainfall events, there is a tendency to develop a layer of reduced permeability that changes to a $2-3 \mathrm{~cm}$ thick crust during the drier period. Crust development is inversely related to stability of soil structure, which in turns depends on organic matter content and exchangeable sodium percentage. In this context, soil management can really make the difference between good and poor soils. In southern Italy, intensive agricultural activities together with pedo-climatic conditions characterized by low soil organic matter content and scarce vegetation cover expose soils to degradation 


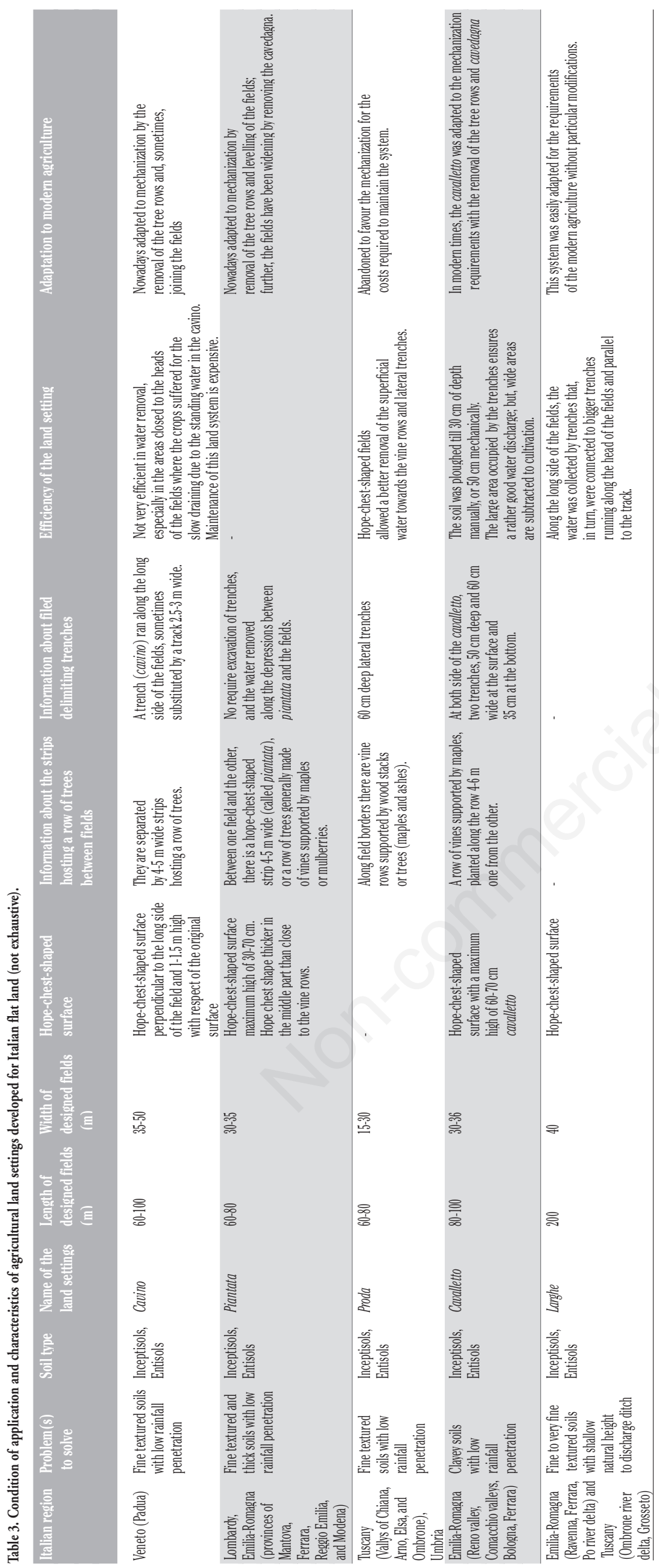


and erosion risks. Frequently, badlands and degraded grasslands have been remodelled for agriculture, mainly to cultivate durum wheat. This farming practice and the abandonment of some of the reshaped areas without hydraulic land-settings maintenance have increased the risk of soil erosion, as manifested by land degradation and diffusion of rills and gullies networks. This has occurred since most of the catchments has fine-textured soils and are cultivated with durum wheat from year to year (Piccarreta et al., 2006).

\section{Plains}

Plain soils are mainly affected by waterlogging. When the excess of water in soil is alternated with soil aeration (because of drainage or evapotranspiration), characteristic redoximorphic features form in the soil layer embraced within the upper and lower water levels; these features are represented by contrasting colouring, with a depleted matrix greyish coloured adjacent to or intricated with reddish soil patches. When waterlogging is permanent or so, strongly redoximorphic conditions occur in the layer under permanent reducing conditions, with the development of a diffuse greyish colour due to the reduction of $\mathrm{Fe}$ - and $\mathrm{Mn}$-oxyhydroxides. Both waterlogging and reducing conditions negatively affect plants and production (Ding et al., 2020; Zhou et al., 2020). In fact, the excess of water causes: i) root asphyxia, with consequent reduction of root expansion and functionality; ii) lowering of microbial activity; iii) loss of nitrates through denitrification and production of toxic ions like $\mathrm{Fe}^{2+}, \mathrm{Mn}^{2+}$, and $\mathrm{S}^{2-}$; iv) increase of cryptogamic diseases; v) increase of weeds resistant to asphyxia like chamomile (Matricaria chamomilla L.), Bermuda grass [Cynodon dactylon (L.) Pers.], Johnson grass [Sorghum halepense (L.) Pers. ] and others.

For all these reasons, various agricultural land settings have been tailored so as to reply to different problems. The depth of the groundwater level controls the soil agricultural use, since each crop needs a minimum soil thickness with aerated conditions to produce at its best. Two kinds of solution are usually adopted to reduce the amount of water in the soil: the creation of a deep drainage system made of buried drains (e.g., Tolomio and Borin, 2019), or a superficial network of water-discharging trenches. Different solutions have been proposed in Italy during time, as reported in Table 3: cavino, piantata, proda, cavalletto, and larghe. Soil surveys we made in 2002 on clay loam to silty clay loam soils from plain land (alluvial parent material) with and without larghe set-up system (Table 4) revealed that soils with set-up system displayed light redoximorphic conditions (presence of mottles) starting at 36-38 $\mathrm{cm}$ of depth that were followed by gley horizons with strongly redoximorphic conditions from the depth of $82-88 \mathrm{~cm}$; instead, the soils with no set-up system showed redoximorphic conditions starting at a depth of about $15 \mathrm{~cm}$ that persisted until the occurrence of gley horizons with strongly redoximorphic conditions at $50-53 \mathrm{~cm}$ of depth. These results indicate that the presence of deep permanent ditches in plain soils are effective in removing water excess even in heavy soils.

In general, waterlogging conditions are nowadays worse than before mostly because of two reasons: i) reduction of time of concentration; and ii) advent of heavy machinery.

i) Over the past half-century, land set-up and reclamation networks have changed due to urbanization and the advent of different soil management. These transformations have implied a number of serious hydraulic dysfunctions that even more frequently result in flooding events. It is not a case that in the last two decades devastating floods occurred in the plains of many Italian regions like Piedmont, Liguria, Veneto, Emilia Romagna, Marche, Tuscany, and Sardinia. It is often reported that changing in rainfall intensity regime plays a role in the increment of disastrous floods, but it is irrefutable that disappearance of land set-up systems and negligence in maintaining the ones still present have played a very important role. For instance, the effects of the network transformations in Veneto were investigated by Sofia et al. (2014), who concluded that over the past half-century soil water-holding capacity has been drastically reduced, resulting in shorter times for soil saturation and time of concentration, this latter being the ideal time needed for water to flow from the most remote point of a watershed to the watershed outlet (Haan et al., 1994). According to Pagliai (2008), the increased erosion due to agricultural intensification of the last 50 years has diminished the time of concentration. This has decreased the soil water-holding capacity of about $30 \%$ at a national level, so activating a negative feedback responsible for erosion increase and consequent water holding capacity decrease.

ii) In the past few decades, the size and weight of agricultural machinery have increased significantly the severity and depth of compacted zone, with consequent collapse of soil structure and waterlogging (Sivarajan et al., 2018). In this respect, Pagliai et al. (2003, 2004) described the compacting effect of rubber tracked tractors in comparison to that of the traditional wheeled tractors on a Vertic Cambisol near Rome. Soil compaction is not only caused by wheel traffic but also to the shear strength of tillage implements, like the compact layer (ploughpan) formed at the lower limit of cultivation in soils frequently ploughed because of a wheat monoculture lasting more than 50 years. This layer is characterised by the strong decrease of elongated transmission pores and hydraulic conductivity (Pagliai et al., 2000). At the catchment scale, waterlogging due to heavy machinery, ploughpan formation and grazing intensification was a potential driver of floods increase and of crop growth and grain yield decrease (Alaoui et al., 2018), since: i) it reduces the soil water infiltration; and ii) it exacerbates the effects of high-intensity rainfall events, always more frequent because of climate change, especially for highly degraded soils and soils characterized by fine texture and low infiltration capacity.

A significant fraction of organic soils (Histosols) located in the low-lying coastal areas of the eastern Po river plain has been reclaimed during the last century by the colmata system (Table 5), which was developed in Tuscany during the Renaissance for reclamation of the Chiana valley and Grosseto plain. Because of the main organic nature of the soils, land subsidence has been the commonly observed response of these soils once reclaimed to agriculture by drainage. According to Antonellini et al. (2019), the natural land subsidence rate in the Holocene sediments of the shallow coastal aquifer of Ravenna (north-eastern Italy) measured in the area was $1-2 \mathrm{~cm}_{\text {year }}{ }^{-1}$, while subsidence rates in drained peaty areas vary from less than 1 to more than $10 \mathrm{~cm}_{\text {year }}{ }^{-1}$. In some of these places, subsidence has reached the level of $2 \mathrm{~m}$ or more. Further observations indicated that, once drained, peaty soils became prone to degradation because of the activation of five phenomena: shrinkage due to desiccation, consolidation, wind and water erosion, burning, and biochemical oxidation. For all these reasons, soil scientists recommend not to drain Histosols that must be maintained in their natural conditions.

\section{Forest ecosystems}

Forestland is the second most common land use type, covering $\approx 29 \%$ of the total Italian area, with the main uses represented by silviculture and pasture (INFC, 2007). It is well-known that moun- 


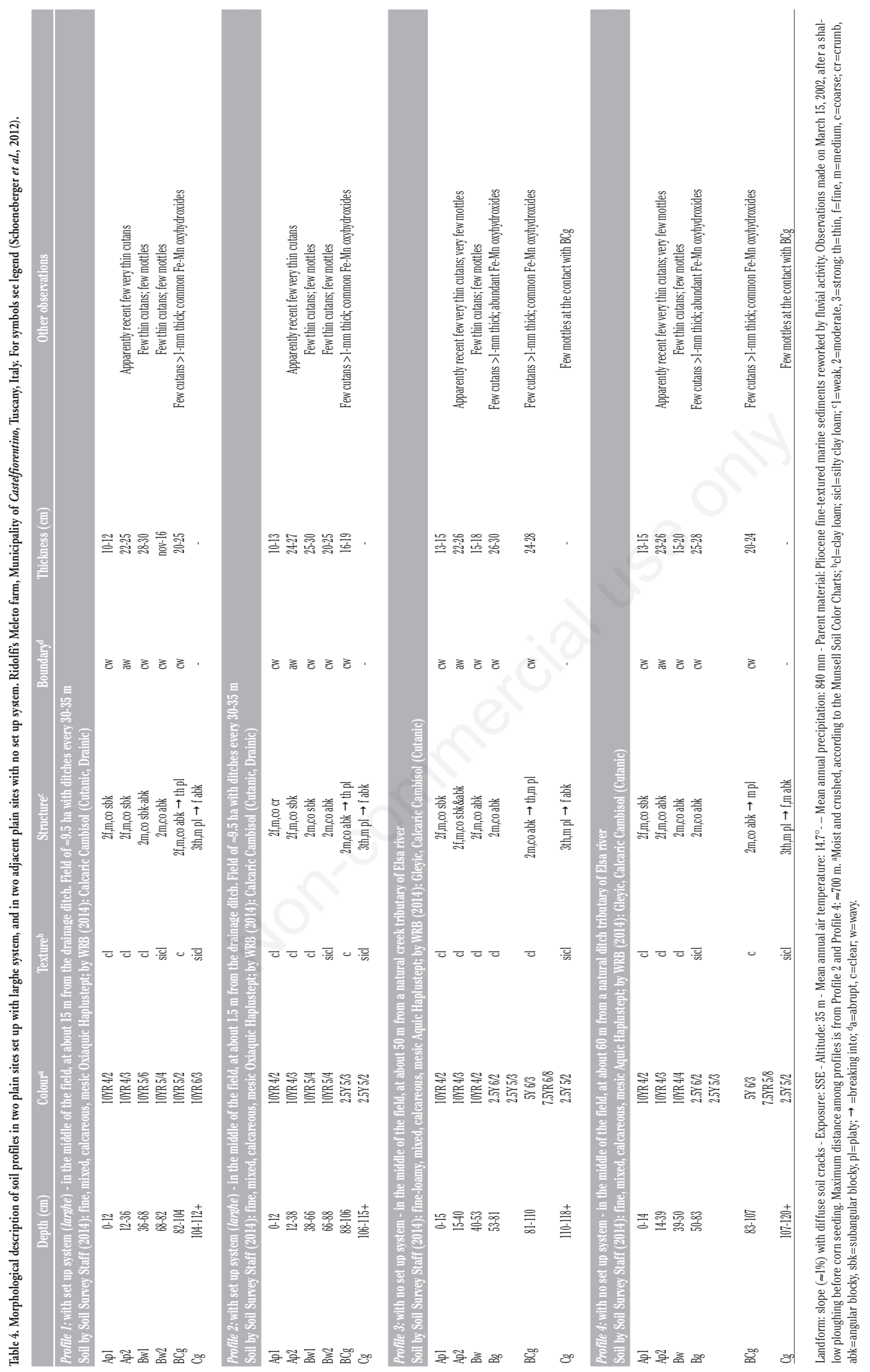


tain and hilly forests provide a variety of important ecosystem services (Corti et al., 2020), including protection against natural or human-triggered hazards like floods, avalanches, and landslides (Vacchiano et al., 2015), but low attention has been devoted to land settings in forest environments. In the last two millennia, anthropogenic disturbances like grazing, fire, and land use changes have been the main drivers of forest dynamics (Romeo et al., 2015; Vacchiano, 2017). These factors remain the main causes of soil erosion, even though in the last decades, in Italy, agriculture (especially cereals, vineyards, and orchards) has been decreasing and several marginal areas have been abandoned, with a corresponding increase of forest areas (Tasser et al., 2007). In a scenario affected by changes of climate and soil use and management, soils of mountain areas require specific attention as they are the most vulnerable to changes. In fact, mountain slope denudation processes are variable in intensity depending mainly on soil features, bedrock structural setting, climate, and relief (Bollati et al., 2019). Further, mountain soils management shows several limitations due to difficult climatic and topographic conditions, and the main obstacles to sustainable agriculture are conservation of soil chemical and physical fertility, and the occurrence of steep slopes and problematic land accessibility, which indirectly affect land conservation especially when marginal areas become prone to slope failures and erosion enhances after abandonment (Curtaz et al., 2015). Grazing lands are mainly distributed in humid and sub-humid ecosystems of Alps and Apennines, and nowadays are degraded by the intensified human disturbance and ongoing climate change. According to Lichtenberger (1994), pastoral activities have been practised on the Alps for 6000 years and have represented fundamental semi-natural habitats for environmental and ecological reasons. In the last century people have moved to the bottom valley, leaving unproductive agro-pastoral systems to be transformed. The main consequence of under-grazing or complete disappearance of permanent pastures has been a progressive entry of shrubs and trees (Cislaghi et al., 2019), but also the abandonment of centuries-old land setting. As a consequence of rural exodus toward cities and coastal areas, in estimating soil degradation in mountain grasslands of the
Autonomous Province of Trento (northeastern Italian Alps), Torresani et al. (2019) observed that the increase in the number of livestock, combined with scarce grazing management and climatic and geomorphic processes, may lead to a general degradation of land setting systems in pastureland. In similar context, drastic interventions of sustainable management of grassland have to be planned in case of widespread erosion, so as to rehabilitate degraded lands, preventing soil losses, and introducing sustainable management of grassland.

Borrelli and Schütt (2014) observed a particular negligence on studies about soil degradation and erosion processes under forest, despite the large Italian forest cover. And this negligence brings up increments of soil erosion and floods as we explained before. The most common and widespread Italian forestry is coppice, with thousands of hectares harvested every year (61,038 ha of coppice were harvested on Italian mountains and hills in the year 2012 only; Istat, 2014, 2015); yet, this land exploitation is carried out without applying appropriate soil conservation practices (Borrelli et al., 2017). Moreover, coppicing is a suitable land use for environments characterized by a wide soil and lithologic spatial heterogeneity, and the occurrence of a mosaic of structurally different forest patches of different age classes ensure a certain slope stability (Scarascia-Mugnozza et al., 2000). Unfortunately, in the last decades, coppices have been frequently converted in high stand forests especially on the Apennines (Nocentini, 2009), favouring soil erosion because of the increased amount and speed of the stemflow (Figure 4) and the lack of appropriate watershed management (Phillips and Marion, 2004; Corti et al., 2019). Stemflow is a primary pathway through which rainwater reaches the ground surface under plants, and contributes to the formation of concentrated flows, which easily trigger rill erosion around the stem base. Especially in the actual climatic conditions characterized by even higher occurrence of summer cyclones bringing highly intense rainfall events in the Alpine and Apennines forests, both negligence in coppice management and conversion of coppice to high stand forests are co-responsible for reducing the time of concentration and, consequently, in producing floods. For all these reasons,

Table 5. Condition of application of Italian drainage systems developed for soil reclamation (not exhaustive).

\begin{tabular}{|c|c|c|c|c|}
\hline Italian region & $\begin{array}{l}\text { Name of the hydraulic } \\
\text { land setting }\end{array}$ & Location & Structure of the hydraulic land setting & Difficulties \\
\hline Tuscany & Colmata (Filling) & Chiana valley (Arezzo), Grosseto plain & $\begin{array}{l}\text { The colmata method consists in diverting the water of a } \\
\text { river or stream in a delimited area, allowing the suspension } \\
\text { to sediment. Because of artificial canals that deflect part of the } \\
\text { water flow, the surface to be reclaimed (cassa di colmata, filling crate), } \\
\text { bordered by a main dyke and subdivided into smaller areas } \\
\text { (casse or preselle, crates) by secondary dikes is flooded. } \\
\text { Once inside the crate, the reduced water flow allows the suspension } \\
\text { to sediment. Thus, the water is left to run away to a canal that brings } \\
\text { the water to the river through a spillway. The size of the sediments is } \\
\text { function of the flow speed, but also of the soils of the watershed. } \\
\text { The small crates inside the big crate are in succession and are } \\
\text { often cultivated during reclamation. }\end{array}$ & $\begin{array}{l}\text { The soils obtained with this system are generally fertile, thanks to their good } \\
\text { chemical properties due to the fine and rich-in-nutrient materials deposited } \\
\text { by the water of the river. In contrast, physical properties of the sediments are } \\
\text { usually poor and require several mechanical works to be improved. } \\
\text { Notwithstanding its efficiency and low costs of achievement, nowadays, this } \\
\text { system has been abandoned because of the long time (20-40 years) required } \\
\text { to obtain a sufficient soil thickness free of water. }\end{array}$ \\
\hline $\begin{array}{l}\text { Emilia Romagna, } \\
\text { Tuscany }\end{array}$ & Mazzuolatura & $\begin{array}{l}\text { Emilia-Romagna: numerous valleys. } \\
\text { Tuscany: Massaciuccoli lake (Lucca), } \\
\text { Bientina swamps (Pisa) }\end{array}$ & $\begin{array}{l}\text { This system achieves the increase of soil surface at a higher level than } \\
\text { discharge collectors through the accumulation of soil material excavated } \\
\text { from trenches opened each 8-10 m one from the other and parallel } \\
\text { to the long side of the field. The soil strips among the trenches are called } \\
\text { mazzuoli, and the network of trenches is responsible for the collection } \\
\text { and removal of water. }\end{array}$ & $\begin{array}{l}\text { After the World War II, this agriculture drainage system was abandoned } \\
\text { because of the high cost of achievement and the } \\
\text { hindrances (numerous trenches, small fields) } \\
\text { that prevent modern agriculture practices }\end{array}$ \\
\hline $\begin{array}{l}\text { Veneto, } \\
\text { Emilia-Romagna, } \\
\text { Latium, Abruzzo, } \\
\text { Sardinia }\end{array}$ & $\begin{array}{l}\text { Drainage system } \\
\text { (prosciugamento) }\end{array}$ & $\begin{array}{l}\text { Veneto: Polesine and Piave lowland, } \\
\text { Adige-Po valley. } \\
\text { Emilia-Romagna: Ravenna, Parma, } \\
\text { Reggio Emilia. } \\
\text { Latium: Agro Pontino. } \\
\text { Abruzzo: Fucino plain. } \\
\text { Sardinia: Arborea. }\end{array}$ & $\begin{array}{l}\text { In this system the excess of water is removed through one or more effluent } \\
\text { ducts running along the watershed lines of the basin. } \\
\text { The physicochemical characteristics of the soils must be considered, } \\
\text { to avoid problems related to their subsidence due to the compaction } \\
\text { occurring after their reclamation. }\end{array}$ & $\begin{array}{l}\text { Water in excess is discharged in the lower areas, sometime draining pumps } \\
\text { are required. This latter option raises the costs of reclamation }\end{array}$ \\
\hline
\end{tabular}



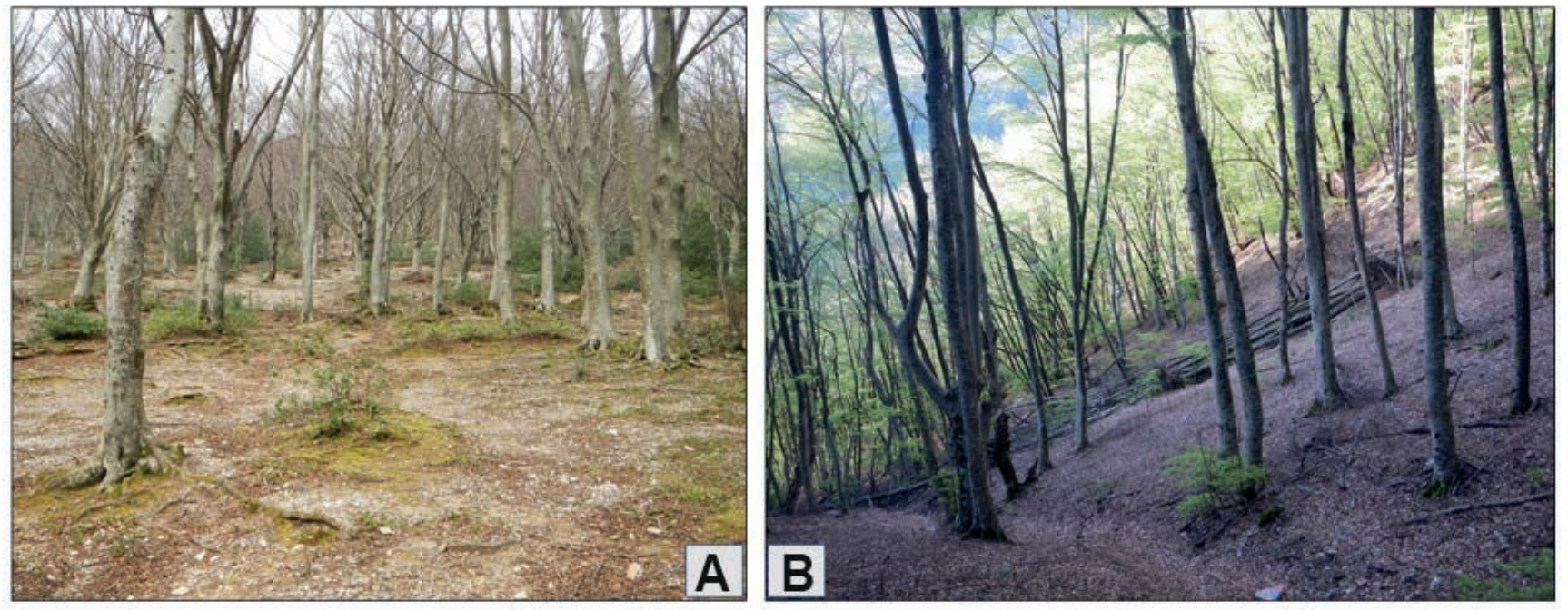

Figure 4. Examples of accelerated erosion in two beech (Fagus sylvatica L.) forests due to the change from coppice to high stand forest. A) Mount Acuto (Pesaro, Italy), on limestone parent material, $\approx 15 \%$ slope; B) Mount Terminillo (Rome, Italy), on limestone parent material, $\approx 45 \%$ slope.

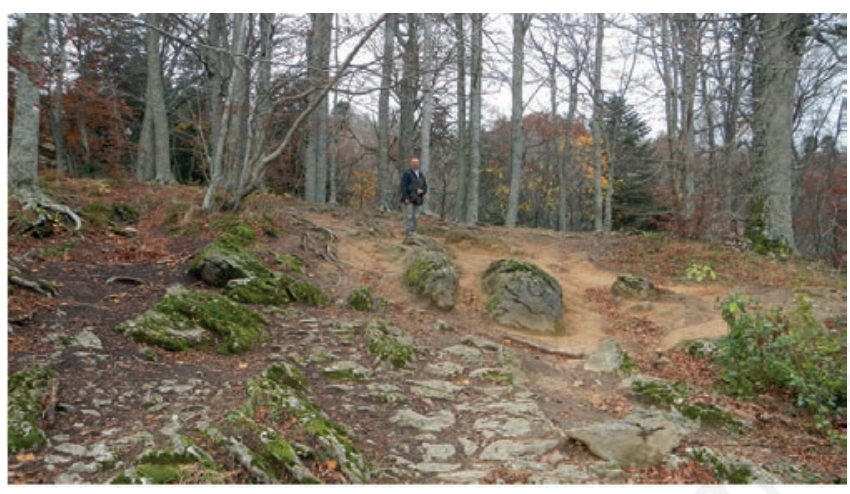

Figure 5. Example of accelerated erosion due to excess of tourist trampling in a beech (Fagus sylvatica L.) forest near the Saint Francis's Sanctuary of La Verna, Chiusi della Verna Municipality, Arezzo, Italy. In an area of about $1000 \mathrm{~m}^{2}$ at about $1200 \mathrm{~m}$ above sea level, about half meter of soil has been removed.

both mountain environments and forest ecosystems need more attention on soil management (Figure 5), to which well-being is strictly connected.

\section{Conclusions}

This paper refers that the adoption of land set-up systems tailored for different soil situations has positive effects on the reduction of soil erosion and increase of soil fertility. This conclusion might be considered as ordinary. Though, we must consider that the development and adoption of many land settings refer to centuries ago, when their large diffusion was certainly due to their efficacy, but scientific information on advantages due to their adoption is scarce, mainly for two reasons: i) in the period of their maximum diffusion, just empirical and practice information was amassed; ii) nowadays, mostly because of economic and mechanization issues, the presence of old land set-up systems is vanishing, being them not substituted by others, except for a superficial tracing of temporary ditches.

However, even with the scarce scientific data and observations, the fact remains that the adoption of permanent land set-up systems must be sewn on the different geological, geomorphological, pedological, and climatic characteristics of the various Italian physiographic regions. The adoption of permanent land set-up systems would have the advantage to increase the time of concentration, so decreasing the probabilities of flooding events in the plain areas. By considering costs of damages due to flooding events, costs for adoption of land set-up systems would transform them into investments at a larger scale. Future challenge in both agricultural and forestry sectors is to give even more importance to the adoption of land settings and to the soil issues at the level of national and European Community interests, so to better manage soil against erosion and water discharge against floods.

\section{Highlights}

Land set-up systems increase soil fertility.

Land set-up systems reduce incidence and seriousness of flooding events.

Land set-up systems need improvement for forest ecosystems. Each soilscape needs its own land set-up system.

\section{References}

Agnelli AE, Corti G, Agnelli A, Del Carlo P, Coltelli M, Ugolini FC, 2007. Features of some paleosols on the flanks of Etna volcano (Italy) and their origin. Geoderma 142:112-6.

Agnoletti M, 2007. The degradation of traditional landscape in a mountain area of Tuscany during the $19^{\text {th }}$ and $20^{\text {th }}$ centuries: Implications for biodiversity and sustainable management. Forest Ecol. Manage. 249:5-17.

Agnoletti M, Errico A, Santoro A, Dani A, Preti F, 2019. Terraced landscapes and hydrogeological risk. Effects of land abandon- 
ment in Cinque Terre (Italy) during severe rainfall events. Sustainability 11:235.

Alaoui A, Rogger M, Peth S, Blöschl G, 2018. Does soil compaction increase floods? A review. J. Hydrol. 557:631-42.

Antonellini M, Giambastiani BMS, Greggio N, Bonzi L, Calabrese L, Luciani P, Perini L, Severi P, 2019. Processes governing natural land subsidence in the shallow coastal aquifer of the Ravenna coast, Italy. Catena 172:76-86.

Bagagiolo G, Biddoccu M, Rabino D, Cavallo E, 2018. Effects of rows arrangement, soil management, and rainfall characteristics on water and soil losses in Italian sloping vineyards, Environ. Res. 166:690-704.

Barbera G, Cullotta S, Rossi-Doria I, Rühl J, Rossi-Doria B, 2009. I paesaggi a terrazze in Sicilia: metodologie per l'analisi, la tutela e la valorizzazione. Collana Studi e Ricerche dell'Arpa Sicilia. Vol. 7. Palermo, Italy.

Bollati IM, Masseroli A, Mortara G, Pelfini M, Trombino L, 2019. Alpine gullies system evolution: erosion drivers and control factors. Two examples from the western Italian Alps. Geomorphology 327:248-63.

Borrelli P, Robinson DA, Fleischer LR, Lugato E, Ballabio C, Meusburger CAK, Modugno S, Schütt B, Ferro V, Bagarello V, Van Oost K, Montanarella L, Panagos P, 2017. An assessment of the global impact of 21st century land use change on soil erosion. Nature Commun. 8:2013.

Borrelli P, Schütt B, 2014. Assessment of soil erosion sensitivity and post-timber-harvesting erosion response in a mountain environment of Central Italy. Geomorphology 204:412-24.

Bracchetti L, Carotenuto L, Catorci A, 2012. Land-cover changes in a remote area of central Apennines (Italy) and management directions. Landscape Urban Plann. 104:157-70.

Calzecchi Onesti A, 1957. Sistemazioni in Collina. Ramo Editoriale degli Agricoltori, Roma, Italy.

Carballo-Arias NA, Ferro V, 2016. Assessing, measuring and modelling erosion in calanchi areas: a review. J. Agricult. Engine. 47:181-90.

Carrari E, Ampoorter E, Bottalico F, Chirici G, Coppi A, Travaglini D, Verheyen K, Selvi F, 2017. The old charcoal kiln sites in Central Italian forest landscapes. Quatern. Int. 458:214-23.

Cislaghi A, Giupponi L, Tamburini A, Giorgi A, Bischetti GB, 2019. The effects of mountain grazing abandonment on plant community, forage value and soil properties: observations and field measurements in an alpine area. Catena 181:104086.

Cocco S, Brecciaroli G, Agnelli A, Weindorf DC, Corti G, 2015. Soil genesis and evolution on calanchi (badland-like landform) of central Italy. Geomorphology 248:33-46.

Corti G, Agnelli A, Cocco S, Cardelli V, Masse J, Courchesne F, 2019. Soil affects throughfall and stemflow under Turkey oak (Quercus cerris L.). Geoderma 333:43-56.

Corti G, Cavallo E, Cocco S, Biddoccu M, Brecciaroli G, Agnelli A, 2011. Evaluation of erosion intensity and some its consequences in vineyards from two hilly environments under a Mediterranean type of climate, Italy. In: D. Godone, S. Stanchi (eds.) Soil Erosion in Agriculture. Chapter 6. InTech Open Access Publisher, Rijeka, Croatia.

Corti G, Cocco S, Brecciaroli G, Agnelli A, Seddaiu G, 2013. Italian Soil Management from Antiquity to Nowadays. In: E.A.C. Costantini, C. Dazzi (Eds.), The Soils of Italy. World Soils Book Series, Springer Science+Business Media, Dordrecht, Germany.

Corti G, Urbinati C, Cocco S, Casucci C, Toscano G, Finco A, Bentivoglio D, Bucci G, Cardelli V, De Bernardi A, Hoseini M,
Malandra F, Mancini M, Rossini G, Serrani D, Tonelli E, Vitali A, 2020. Forests and Soils: Sustainable Products and Ecosystem Services for Human Well-Being. In: S. Longhi, A. Monteriù, A. Freddi, M.G. Ceravolo, O. Carnevali, M. Giordano, G. Moroncini (Eds.), The First Outstanding 50 Years of "Università Politecnica delle Marche". Springer, Cham. pp 617-630.

Costantini EAC, Barbetti R, 2008. Environmental and visual impact analysis of viticulture and olive tree cultivation in the province of Siena (Italy). Eur. J. Agron. 28:412-26.

Costantini EAC, Fantappié M, L'Abate G, 2013. Climate and Pedoclimate of Italy. In: E.A.C. Costantini, C. Dazzi (Eds.), The Soils of Italy. World Soils Book Series. Springer, Dordrecht, Germany.

Curtaz F, Stanchi S, D’Amico ME, Filippa G, Zanini E, Freppaz M, 2015. Soil evolution after land-reshaping in mountains areas (Aosta Valley, NW Italy). Agric. Ecosyst. Environ. 199:238-48.

Dazzi C, 2007. Environmental features and land use of Etna (Sicily - Italy). In: Ò. Arnalds, F. Bartoli, P. Buurman, H. Òskarsson, G. Stoops, E. Garcia-Rodeja (Eds.), Soils of volcanic regions in Europe. Springer, Berlin, Germany.

Dazzi C, Costantini EAC, 2015. The history of terracing. A box in Chapter II - Mountain soils and agriculture. In: R. Romeo, A. Vita, S. Manuelli, E. Zanini, M. Freppaz, S. Stanchi (Eds.), Understanding mountain soils. A contribution from mountain areas to the International Year of Soils 2015. FAO, Rome, Italy, pp 28-29.

Dazzi C, Lo Papa G, 2013. Soil threats. In: E.A.C. Costantini, C. Dazzi (Eds.), The soils of Italy. World Soils Book Series. Springer, Dordrecht, Germany.

Desplanques H, 1975. Campagne umbre: contributo allo studio dei paesaggi rurali dell'Italia centrale. Quaderni Regionali dell'Umbria, Perugia, Italy.

Di Peco D, Cocco S, Agnelli A, Corti G, 2009. Prié blanc, la resistenza alla fillossera deriva dal rapporto con il suolo. Vignevini 36:48-52.

Ding J, Liang P, Wu P, Zhu M, Li C, Zhu X, Gao D, Chen Y, Guo $\mathrm{W}, 2020$. Effects of waterlogging on grain yield and associated traits of historic wheat cultivars in the middle and lower reaches of the Yangtze River, China. Field Crops Res. 246:1-11.

Esposito G, Matano F, Molisso F, Ruoppolo G, Di Benedetto A, Sacchi M, 2017. Post-fire erosion response in a watershed mantled by volcaniclastic deposits, Sarno Mountains, Southern Italy. Catena 152:227-241.

Freppaz M, Agnelli A, Drusi B, Stanchi S, Galliani C, Revel Chion V, Zanini E, 2008. Soil quality and fertility: Studies in the Valle d'Aosta. In: E. Fontanari, D. Patassini (Eds.), Terraced landscapes of the Alps. Projects in progress Marsilio Publisher, Venice, Italy, pp 37-39.

Haan CT, Barfield BJ, Hayes JC, 1994. Design hydrology and sedimentology for small catchments. Academic Press, Elsevier, The Netherlands.

INFC (Inventario Nazionale delle Foreste e dei Serbatoi Forestali di Carbonio), 2007. Le stime di superficie 2005. Ministero delle Politiche Agricole, Alimentari e Forestali, Ispettorato Generale e Corpo Forestale dello Stato, CRA e Istituto Sperimentale per l'Assestamento Forestale e l'Alpicoltura, Trento, Italy.

Istat (Istituto Nazionale di Statistica), 2013. Ambiente e territorio. Capitolo 1, pp 1-28. In: P. Cacioli (ed.) Annuario Statistico Italiano 2013. Istat, Roma, Italy.

Istat (Istituto Nazionale di Statistica), 2014. Dati statistici Foreste 
e silvicoltura. Istat, Roma, Italy. Available from: http://agri.istat.it/sag_is_pdwout/jsp/Introduzione.jsp?id=7A

Istat (Istituto Nazionale di Statistica), 2015. Webpage. Istat, Roma, Italy. Available from: http://www.istat.it/en/

Landi R, 1999. Agronomia e Ambiente. Edagricole, Bologna, Italy, $656 \mathrm{pp}$.

Lichtenberger E, 1994. Österreochiske Acad. Wissenshaften, Veröffentlichungen der Kommision für Humanökologie 5:5386.

Lo Papa G, 2013. The genetic erosion of soil ecosystem. Int. Soil Water Conserv. Res. 1:11-8.

Lo Papa G, Palermo V, Dazzi C, 2011. Is land-use change a cause of loss of pedodiversity? The case of the Mazzarrone study area, Sicily. Geomorphology 135:332-42.

Mauro G, 2015. Terraced landscape in the coastal area of Trieste (NorthEastern Italy) between neglecting problems and tourism opportunities. Paesaggi terrazzati in costiera triestina, tra problematiche di abbandono e ipotesi di ri-valutazione turistica. Docum. Geogr. 2:67-89.

Nocentini S, 2009. Structure and management of beech (Fagus sylvatica L.) forests in Italy. iForest - Biogeosci. Forestry 2:10513.

Pagliai M, 2008. La prevenzione della degradazione del suolo per una gestione sostenibile. In: Proceedings of the Congress "Conservazione e fertilità del suolo, cambiamenti climatici e protezione del paesaggio", Decembre 10-11, Roma, Italy.

Pagliai M, Marsili A, Servadio P, Vignozzi N, Pellegrini S, 2003. Changes in some physical properties of a clay soil in Central Italy following the passage of rubber tracked and wheeled tractors of medium power. Soil Till. Res. 73:1-2.

Pagliai M, Pellegrini S, Vignozzi N, Rousseva S, Grasselli O, 2000. The quantification of the effect of subsoil compaction on soil porosity and related physical properties under conventional to reduced management practices. Adv. GeoEcol. 32:305-13.

Pagliai M, Vignozzi N, Pellegrini S, 2004. Soil structure and the effect of management practices. Soil Till. Res. 79:131-43.

Phillips JD, Marion DA, 2004. Pedological memory in forest soil development. Forest Ecol. Manage. 188:363-80.

Piccarreta M, Capolongo D, Boenzi F, Bentivenga M, 2006. Implications of decadal changes in precipitation and land use policy to soil erosion in Basilicata, Italy. Catena 65:138-51.

Romeo R, Vita A, Manuelli S, Zanini E, Freppaz M, Stanchi S (Eds.), 2015. Understanding mountain soils. A contribution from mountain areas to the International Year of Soils 2015. FAO, Rome, Italy.

Sandor JA, 2006. Ancient agricultural terraces and soils. In: B. Warkentin (Ed.), Footprints in the soil: people and ideas in soil history. Elsevier, Amsterdam, The Netherlands, pp 505-534.

Scaramellini G, Varotto M, 2008. Terraced landscapes of the Alps. Atlas ALPTER Project, Marsilio Editori, Venezia, Italy.

Scarascia-Mugnozza G, Oswald H, Piussi P, Radoglou K, 2000. Forests of the Mediterranean region: gaps in knowledge and research needs. Forest Ecol. Manage. 132:97-109.

Schoeneberger PJ, Wysocki DA, Benham EC, 2012. Soil survey staff. Field book for describing and sampling soils, Version 3.0. Natural Resources Conservation Service. National Soil Survey Center, Lincoln, NE, USA.
Sereni E, 1961. Storia del paesaggio agrario italiano. Laterza, Roma, Italy.

Sivarajan S, Maharlooei M, Bajwa SG, Nowatzki J, 2018. Impact of soil compaction due to wheel traffic on corn and soybean growth, development and yield. Soil Tillage Res. 175:234-43.

Sofia G, Prosdocimi M, Dalla Fontana G, Tarolli P, 2014. Modification of artificial drainage networks during the past half-century: Evidence and effects in a reclamation area in the Veneto floodplain (Italy). Anthropocene 6:48-62.

SSS (Soil Survey Staff), 2014. Keys to soil taxonomy, twelfth edition. United States Department in Agriculture Natural Resources Conservation Service, Washington, DC, USA.

Stanchi S, Freppaz M, Agnelli A, Reinsch T, Zanini E, 2012. Properties, best management practices and conservation of terraced soils in Southern Europe (from Mediterranean areas to the Alps): a review. Quatern. Int. 265:90-100.

Stanchi S, Freppaz M, Godone D, Zanini E, 2013. Assessing the susceptibility of alpine soils to erosion using soil physical and site indicators. Soil Use Manage. 29:586-96.

Tarolli P, Preti F, Romano N, 2014. Terraced landscapes: From an old best practice to a potential hazard for soil degradation due to land abandonment. Anthropocene 6:10-25.

Tasser E, Walde J, Tappeiner U, Teutsch A, Noggler W, 2007. Land-use changes and natural reforestation in the Eastern Central Alps. Agricult. Ecosyst. Environ. 118:115-29.

Tolomio M, Borin M, 2019. Controlled drainage and crop production in a long-term experiment in NorthEastern Italy. Agric. Water Manage. 222:21-9.

Torresani L, Wu J, Masin R, Penasa M, Tarolli P, 2019. Estimating soil degradation in montane grasslands of North-eastern Italian. Heliyon 5:e01825.

Torri D, Bryan R, 1997. Micropiping processes and biancana evolution in southeast Tuscany, Italy. Geomorphology 20:219-35.

Torri D, Colica A, Rockwell D, 1994. Preliminary study of the erosion mechanisms in a biancana badland (Tuscany, Italy). Catena 23:281-94.

Vacchiano G, Garbarino M, Lingua E, Motta R, 2017. Forest dynamics and disturbance regimes in the Italian Apennines. Forest Ecol. Manage. 388:57-66.

Vacchiano G, Maggioni M, Perseghin G, Motta R, 2015. Effect of avalanche frequency on forest ecosystem services in a sprucefir mountain forest. Cold Regions Sci. Technol. 115:9-21.

Vergari F, Della Seta M, Del Monte M, Barbieri M, 2013. Badlands denudation "hot spots": the role of parental material properties on geomorphic processes in 20 years monitored sites of Southern Tuscany (Italy). Catena 106:31-41.

WRB (World Reference Base for Soil Resources), 2014 (update 2015). International soil classification system for naming soils and creating legends for soil maps. World Soil Resources Reports No. 106. FAO, Rome, Italy.

Zimmermann RC, 2006. Recording rural landscapes and their cultural associations: some initial results and impressions. Environ. Sci Policy 9:360-9.

Zhou W, Chen F, Meng Y, Chandrasekaran U, Luo X, Yang W, Shu K, 2020. Plant waterlogging/flooding stress responses: from seed germination to maturation. Plant Physiol. Biochem. 148:228-36. 